\title{
FEEDING INFANTS WITH COW'S MILK AND SOY ALLERGY: SOCIAL AND ECONOMIC ASPECTS OF EFFICACY
}

\author{
Irēna Putnina* Silvija Remberga**, and Ingrīda Rumba-Rozenfelde** \\ * Faculty of Biology, University of Latvia, Kronvalda bulv. 4, LV-1586, Rīga, LATVIA \\ ** Faculty of Medicine, University of Latvia, Raiṇa bulv. 19, LV-1586, Rīga, LATVIA
}

Contributed by Ingrïda Rumba-Rozenfelde

\begin{abstract}
Allergy to cow's milk protein and/or soy is common among allergic diseases in infants. They appear at an early infant stage and remain important in clinical practice from one up to three years. According to clinical research, cow's milk allergy affects about 1.9-4.9\% of babies and infants, respectively, and in addition some of them also suffer from soy protein allergy. Dietary prevention of allergic protein by its elimination in food is a significant part of treatment, and allows adequate development of babies and restricts the risk of progressive allergic diseases. Securing exclusive breastfeeding is one of the basic principles in successful therapy treatment. However, there are cases when breastfeeding does not prevent the development of cross milk protein allergy. Only adequate special feeding formulas can provide both energy needs and sufficient quantity of proteins (8.9-11.5\%) in food when breastfeeding is not possible. Knowledge of effective compensation mechanisms become apparent by analysing the situation in Europe and USA in the area of different available feeding formulas using both the medical insurance system and randomised formula providing tolerance of the mixture at about $90-95 \%$. The goal of research was to determine the correlation between the availability of a special mixture, parental adherence and treatment outcomes. Applying special formulas is a routine part of treatment, and there is no doubt about its efficacy. No compensation mechanisms exist in present-day Latvia, and the current complicated economic situation in Latvia reduces the ability of parents to choose and buy appropriate formula food. Therefore, a substantial part of therapy treatment is unavailable to infants. Dietary prevention of allergic diseases in infants and small children in Latvia needs special consideration also because of poor knowledge of parents regarding the real situation.
\end{abstract}

Key words: cow's milk protein allergy, soy allergy, breastfeeding, special formulas, reimbursement system.

\section{INTRODUCTION}

Cow's milk protein and/or soy allergies are common in infants. They appear at an early infant stage and remain important in clinical practice from one up to three years. This problem has arisen through a historical tradition to diversify infant feeding with cow's milk. One of the causes for this rarely observed allergy was the rapid increase in the use of artificial feeding formulas in the $20^{\text {th }}$ century, accompanied by aggressive marketing policy of their manufacturers. As a result, the importance of breastfeeding was compromised and the percentage of breast-fed infants fell dramatically. For example, in the 1970s in the USA, about $75 \%$ of babies were formula fed. From this time, the incidence of allergic disease amongst early babies stages grew noticeably. Now two tendencies have become urgent: dietary intervention for primary allergy prevention and providing appropriate feeding in the cases of allergic manifestation (Mavroudi et al., 2011). The last wide report made by Cohrana highlights the efficacy of exclusive breastfeeding in both prevention and treatment of allergy (Host et al., 2008).

Statistics on the estimated incidence of cow's milk protein allergy in infants varies in different counties. The European Paediatrician Association performed a Europe-wide study on clinical practice for ambulatory treatment in cases of cow's milk protein based allergy. It was found that during prime medical care, $47 \%$ of doctors selected the diagnosis of "allergy caused by cow's milk proteins"; on the other hand, allergy specialists have found that this type of allergy affects only an estimated one to three percent of babies. Confusingly, the amount of parents considering their infants suffering of cow's milk or other kind of allergy is between 5 and 20 percent (Venter et al., 2006). No other native milk instead of cow's milk can be used effectively, despite regularly arising promising prospects (D`Auria, 2011). Soy is a genetically modified product provoking cross allergy and food tolerance in infants (Kattan, 2011). Food allergy is a 
cause of bullying in behaviour of children with negative consequences in their future life quality (Schemech, 2012).

\section{NOURISHMENT-PROVOKED ALLERGY — REAL OR TEMPORARY, INAPPROPRIATE NUTRITION CAUS- ING PROBLEMS}

According to data of some other clinical research, cow's milk protein allergy prevalence in infants and babies ranges from 1.9 to 4.9 per cent. In addition, some of them also suffer from soy protein allergy. Nourishment-provoked allergy also could be connected with raised IgE or allergy specific secretion of IgG. It has been strongly shown that allergic disease impedes the quality of a babies' life, and the negative effect can increase for teenagers and families as a whole. Therefore, the correct diagnosis and appropriate therapy becomes one of the most significant problems for paediatricians. Detection of protein causing allergy, and its elimination, is an important part of treatment. Use of hypoallergenic formulas combined with restricting dietary intervention, chosen by parents singly, can cause insufficiency of nutrition, causing problems in future physical development of children (Carafelli, 2010).

The problem of nourishment allergy in infants in Latvia has not been widely studied. A research group at the University of Latvia conducted an inquiry of 500 parents with children under the age of 5. In this study, in children feeding pathology symptoms of the skin, respiration system, digestive apparatus were identified in about $25 \%$ of cases (Rumba et al., 2009).

The elimination of the protein provoking allergy from the diet has a significant role in the treatment of allergy. It helps to provide the adequate development of children and to diminish the risk of prolongation of allergy diseases. Therefore, the correct diagnosis is needed for choosing an appropriate treatment, including special formula fed in accordance with guidelines of ESPACI and ESPGHAN (Host et al., 1997).

\section{ELIMINATIVE DIETS, BREASTFEEDING SUPPORT}

Supporting and promotion of breastfeeding is the first step providing necessary nourishment to infants (Niel et al., 2010). However, there are cases when breastfeeding does not prevent the development of cross milk protein allergy (Brill, 2009). When breastfeeding is not possible, only use of appropriate feeding formula can cover an infants' energetic requirements, which can provide the sufficient amount of protein in food (from 8.9 to 11.5 per cent). It is important to take into consideration that when inflammation factors increase (because of skin or intestinal canal injuries) connected with decreased absorption of nutrients, a dangerous possibility of malnutrition arises even in the case of special nourishing. When the diagnosis has been incorrect or it has not been proven later, the elimination method and use of feeding formula is expensive and non-effective (Meyer et al., 2012).

The situation of Latvia in the field of cow's milk protein and soy protein allergy diagnosis is comparable with data given by research of the European Paediatrician Association. Only a limited part of patients obtain a confirmed diagnosis from an allergy specialist. Mainly, diagnosis is defined during prime medical care, and is based on anamnesis and clinical manifestation. After the prime medical care, as a rule, dietary prescriptions are given to the mother and breastfeeding is promoted; in some cases feeding formula is recommended, but often it is without any result due to lack of parents' being informed and training. Dietary prevention of allergic diseases in infant and small children in Latvia needs special consideration also because of poor knowledge of parents of the real situation and their wrong beliefs (Hays, 2012).

\section{FORMULA FEEDING COMPENSATION POSSIBILI- TIES: COMPARATIVE OVERVIEW}

Formula fed products are expensive and in combination with non-correct diagnosis their efficacy is low (Remberga, 2009).

The average cost of medical feeding formula ranges from 0.30 to $1.27 \mathrm{Ls}$ per $100 \mathrm{ml}$ of usable mixture.

During the first half-year of life, an infant needs about $850-900 \mathrm{ml}$ of usable mixture average per day and 600-700 $\mathrm{ml}$ of usable mixture per day. This amounts to 81.00 to 342.90 Ls for one baby.

According to data of the Latvian Central Statistics Department (11.06.2012), food expenses per one member of household per month were 50,47 Ls. Visibly non-useful and probably dangerous expenses should be excluded.

Thus, it is possible to conclude that high expenses of feeding formula combined with a low information level amongst parents, leads to non-use of feeding formula, or that it is used side by side with cow's milk or soy protein-containing food; so the treatment efficacy planned could not be gained.

The trends described above exist for more than some decades, not only in the USA and developed members of the European Union, but also in Estonia, where formula fed products are included in lists of medicaments and remedies to be compensated. In Estonia, for example, medical feeding formula has been compensated for 2000 children for a period from birth till 12 months of age, corresponding to diagnosis by International classification of diseases SSK10-K52.2; K90.4; L20.8; L27.2. Parents have only to prepay 1.27 Euro for a doctor's prescription, when 10 units are prescribed simultaneously. Diagnosis is arranged by the family doctor or by a paediatrician. No additional examination is required for clinic manifestation and a family's history is sufficient. The system described above is easily real- 
ised and sufficiently effective, but hyper-diagnostic risks are still possible.

When analysing the situation in accordance with accessibility of feeding formula to parents in Europe and the USA, effective compensative mechanisms exist through the medical insurance system and randomised prescription providing tolerance of formula fed at 90-95\% (Niggemann et al., 2008).

In Netherlands, on the other hand, the eliminative protocol completed by provocation test has been confirmed. Those who work in the area of primary care need to meet the requirements of said protocol; only later formula for compensative mixture could be prescribed (or not prescribed). If it is necessary to clarify the diagnosis, a patient can be sent to a specialist. In Bulgaria only specialists (allergologists or gastroenterologists) are allowed to write prescriptions. In Germany expenses are covered by means of the medical insurance system. In Lithuania only synthetic amino acid formula mixtures are included in the list of compensative medicaments; the recipe could be prescribed only by a narrow list of specialists allowed to write prescriptions for compensative medical formula fed, and annual quota exist.

\section{PARENTS AND ALLERGY SPECIALISTS: COLLABO- RATIVE ACTIVITIES; INFORMATION ACCESSIBIL- ITY AND FEEDBACK}

The role of the educational level of parents and their participation in treatment of allergies cannot be underestimated. Research conducted in the USA in 2008/2009 showed that the role of parents is very high not only in treatment of infants' allergy, but also during the school years. In total, 2495 respondents took part in the inquiry fully, and 558 respondents participated in different interrogatories partially. The best knowledge and most participation was amongst those of parents, who were visiting an allergy specialist regularly, in comparison with those who preferred prime care doctors (Gupta et al., 2010).

Taking into account the high expenses of feeding formula and insufficient knowledge and level of parents' participation creates a situation whereby the infant is not able to receive sufficient nutrition. As a result it becomes possible to predict an increase of allergy diseases in the nearest future, especially in cases of real cow's protein allergy — not only milk intolerance. A special feedback providing algorithm is necessary due to prevailing empiric healing consequences (Meyer, 2008).

It would be necessary to implement a unified system for cow's milk and soy protein allergy diagnosis in Latvia in accordance with the important needs of infants, excluding unsuitable use of special feeding formula when allergy due to milk and soy proteins has not been confirmed. On the other hand, when the treatment of young children depends on elimination of proteins, feeding formalas can protect children from future progress of allergy.
Now special formula compositions are available for consumers in Latvia not only in pharmacies but in also supermarkets and shops for children's goods - in contradiction to other states of European Union, where special formula fed compositions can be bought only in pharmacies, as medically prescribed products.

We analysed the experience of parents in using special fed formula compositions. The summary was based on enquiry of parents within the frame of the state research programme "Scientific study on main pathologies and factors exposing to danger the lifelong and life quality of Latvian inhabitants by means of multidiscipline research consortium". The work took part as the sub-project "Modern early diagnosis, prophylaxis and therapy of diseases provoking invalidity and mortality of children". We came to the conclusion that parents, when making a decision about which feeding formula composition to use, including special ones, act on the advice of relatives and friends; thereby, the used formula compositions change, parents begin feeding and assess the results themselves, without being consulted by specialist. An allergy nutrition compensating mechanism for babies in Latvia does not exist, thereby restricting a parents' ability to buy the appropriate medical formula compositions, which causes future manifestation of allergy diseases. Also, the connection between all participants - prime care specialists, allergists and parents supported by contionious feedback and state thoughtful policy could be able to significantly control food allergy effects.

\section{CONCLUSIONS}

In most cases parents in Latvia lack understanding about possible diseases of infants and the principles of their treatment; they are more convinced about the effectiveness of medicaments than about the importance of nourishment.

Cooperation between prime care specialists, allergists and parents could evade hyper diagnostics of allergy and unproved applying of an elimination diet.

A babies' allergy nutrition compensating mechanism in Latvia does not exist, thereby restricting a parents' ability to buy appropriate medical formula fed compositions; this causes future manifestation of allergy diseases.

It would be preferable to apply the experience of other countries and to diagnose cow's milk and soy protein food allergy in good time using unified criteria. This approach could provide the possibility of using special fed formula in cases when it is necessary, creating a mechanism of supplying free medical feeding for infants under the age of one year.

\section{REFERENCES}

Anonymous (2012). Estonian Health Insurance Fund. http://www.haigekassa.ee/eng/service/medicinal-products (last accessed 20 August 2012).

D’Auria, E., Mandelli, M., Ballista, P., Di Dio, F., Giovannini, M. (2011). Growth impairment and nutritional deficiencies in a cow's milk-allergic in- 
fant fed by unmodified donkey's milk. Case Rep. Pediatr., September. http://www.hindawi.com/crim/pediatrics/2011/103825/ (last accessed 2 October 2013).

Berg, A., Kramer, U., Link, E., Bollrath, C., Heinrich, J., Brockow, I., Koletzko, S., Grubl, A., Filipiak-Pittroff, B., Wichmann, H.-E., Bauer, C.-P., Reinhardt, D., Berdel, D., GINIplus study group. (2010). Impact of early feeding on childhood eczema: development after nutritional intervention compared with the natural course-the GINI plus study up to the age of 6 years. Clin. Exper. Allergy, 40, 627-636

Brill, H. (2008). Approach to milk protein allergy in infants. Can. Fam. Physician, 54 (9), 1258-1264.

Caffarelli, C., Baldi, F., Berdandi, B., Calzoen, L., Marani, M., Pasquinelli, on behalf of EWGPAG. (2010). Cow's milk allergy in children: Practical guide. Ital. J. Pediatr., 36, 5.

Gupta, R. S., Springston, E. E., Smith, B., Kim, J. S., Pongracic, J. A., Wang, X., Holl, J. (2010). Food allergy knowledge, attitudes, and beliefs of parents with food-allergic children in the United States. J. Pediatr. Allergy Immunol., 21, 927-934.

Host, A., Halken, S., Muraro, A., Dreborg, S., Niggemann, B., Aalberse, R., Arshad, SH., von Berg, A., Carlsen, K. H., Duschen, K., Eigenmann, P. A., Hill, D., Jones, C., Mellon, M., Oldeus, G., Oranje, A., Pascual, C., Prescott, S., Sampson, H., Svartengren, M., Wahn, U., Warner, J. A., Warner, J. O., Vandenplas, Y., Wickman, M., Zeiger, R. S. (2008). Dietary prevention of allergic diseases in infant and small children. J. Pediatr. Allergy Immunol., 19, 1-4.

Host, A., Koletzko, B., Dreborg, S., Murano, A., Wahn, U., Aggett, P., Bressen, J. I., Hernell, O., Lafebek, H., Michaelsen, K. F., Micheli, I. L., Rigo, J., Weaver, L., Heymans, H., Strobel, S., Vanderplas, Y. (1999). Joint statement of the European Society for Paediatric Allergology and Clinical Immunology (ESPACI) and European society for Paediatric Gastroenterology, Hepatology and Nutrition (ESPGHAN): Dietary products used in infant for treatment and prevention food allergy. Arch. Dis. Child., 81, 80-84.

Kattan, J. D., Cocco, R. R., Jarvinen, K. M. (2011). Milk and soy allergy. Pediatr. Clin. North Amer., 58 (2), 407-426.

Kneepkens, F., Meijer, Y. (2009). Clinical practise. Diagnosis and treatment of cow`s milk allergy. Eur. J. Pediatr., 168, 891-896.
Mavroudi, A., Xinias, I. (2011). Dietary intervention for primary allergy prevention in infants. Hipokrati, 15, 216-222.

Meyer, R., Venter, K., Fox, A. T., Shah, N. (2012). Practical dietary management of protein energy malnutriton in young children with cow's milk protein allergy. J. Pediatr. Allergy Immunol., 23, 307-314.

Meyer, R. (2008). New guidelines for managing cow`s milk allergy in infants. J. Fam. Health Care, 18 (1), 27-30.

Niel, M., Labbok, M., Abrahams, S. (2010). What are the risks associated with formula feeding? A re-analysis and review. Birth, 37, 50-58.

Niggemann, B., von Berg, A., Bollrath, C., Berdel, D., Schauer, U., Rieger, C., Haschke-Becher, E., Wahn, U. (2008). Safety and efficacy of new extensively hydrolyzed formula for infants with cow`s milk protein allergy. $J$. Pediatr. Allergy Immunol., 19, 348-354.

Remberga, S., Trapiņa, I., Sjakste, T., Rumba-Rozenfelde, I. (2009). Uztura alerğija bērniem - alerğisko slimību riska faktors [Food allergy in children — risk factor of allergic diseases].. Grām.: Rumba-Rozenfelde, I. (red.). Bērnu slimību riska faktori (67.-102. 1pp.). Rīga: LU Akadēmiskais apgāds (in Latvian).

Ring, J. (2012). Davos Declaration: Allergy as a global problem. Allergy, 67, $141-143$.

Shemech, E., Annunziato, R. A., Ambrose, A. M., Ravis, L. N., Mullarkey, C., Rubes, M., Chuang, K., Sicherer, M., Sicherer, S. (2013). Child and parental reports of bullying in a consecutive sample of children with food allergy. Pediatrics, 131, e10-e17.

Venter, C., Pereira, B., Grudy, J., Bernie, C. C., Graham, R., Bernie, H., Taraneh, D. (2006). Incidence of parentally reported and clinically diagnosed food hypersensitivity in the first year of life. J. Allergy Clin. Immunol., 117, 1118-1124.

Yin, Y-Y., Cao, R-M., Chen, J., Kaku, Y., Wu, J., Cheng, Y., Shimizu, T., Takase, M., Wu, S.-M., Chen, T.-X. (2011). Partially hydrolized cow's milk formula has a theurapeutic effect on the infant with mild to moderate atopic dermatitis: A randomized, double-blind study. J. Pediatr. Allergy Immunol., 22, 688-694

Mišak, Z. (2011). Symposium II: Infant and childhood nutrition and disease. Infant nutrition and allergy. Proc. Nutr. Soc., 70, 465-471.

Received 24 September 2013

\section{BĒRNU AR GOVS PIENA UN SOJAS ALERGIJU ĒDINĀŠANAS EFEKTIVITĀTES SOCIĀLI EKONOMISKIE ASPEKTI}

Govs piena olbaltuma alerğija un/vai sojas alerǵija ir viena no pirmajām alerğisko slimību izpausmēm, kas sākas jau agrīni zīdaiṇa vecumā un ir klīniski nozīmīga līdz 1-3 gadu vecumam. Saskaṇā ar klīnisko pētījumu datiem govs piena olbaltuma alerğijas izplatība ir no 1,9 līdz 4,9\% zīdaiṇu un mazu bērnu vidū, daḷai no šiem bērniem ir arī sojas olbaltuma alerğija. Ārstēšanas nozīmīga daḷa ir izraisošā olbaltuma alergēna eliminēšanai no uztura, lai nodrošinātu adekvātu bērna attīstību un mazinātu risku tālākai alerǵisko slimību attīstībai. Ekskluzīvas zīdīšanas nodrošināšana ir viens pamatnosacījumiem veiksmīgai uztura terapijai. Gadījumos, kad tas nav iespējams, tikai adekvāta ārstnieciskā maisījuma lietošana mākslīgi èdinātiem bērniem spēj nodrošināt enerǵêtiskās vajadzības un pietiekamu olbaltuma daudzumu no 8,9 līdz 11,5\% uzturā. Eiropas un ASV situācijas analīze par maisījumu pieejamību vecākiem parāda efektīva kompensācijas mehānisma darbību, gan izmantojot veselības apdrošināšanas sistēmu, gan receptūru, kas pierādītas alerğijas gadījumā nodrošina maisījumu toleranci par $90-95 \%$. Ārstniecisko maisījumu lietošana ir ikdienas terapijas daḷa, tās lietderība netiek apšaubīta. Latvijā kompensācijas mehānisms neeksistē, un valstī esošā ekonomiskā situācija ierobežo vecāku iespēju iegādāties maisījumus, līdz ar to bērnam nav iespēju saņemt nepieciešamo terapijas daḷ. 